\title{
Effect of Seaweed Aqueous Extracts and Compost on Vegetative Growth, Yield, and Nutraceutical Quality of Cucumber (Cucumis sativus L.) Fruit
}

\author{
Radames Trejo Valencia ${ }^{1}$, Ludy Sánchez Acosta ${ }^{2}$, Manuel Fortis Hernández ${ }^{2, *} *$, \\ Pablo Preciado Rangel ${ }^{2}$, Miguel Ángel Gallegos Robles ${ }^{3}$, Rocío del Carmen Antonio Cruz ${ }^{4}$ and \\ Cirilo Vázquez Vázquez ${ }^{3}$ \\ 1 Tecnologico Nacional de México/Instituto Tecnológico de Minatitlán, Blvd. Institutos Tecnológicos S/N, \\ Col. Buena Vista Norte, Minatitlán, Veracruz 96848, Mexico; radamestv@hotmail.com \\ 2 Tecnologico Nacional de México/Instituto Tecnologico de Torreón, Maestría en Ciencias en Suelos, \\ Carretera Torreón-San Pedro Km 7.5, Ejido Ana, Torreón, Coahuila 27170, Mexico; \\ ludy.jsa21@gmail.com (L.S.A.); ppreciador@yahoo.com.mx (P.P.R.) \\ 3 Universidad Juárez del Estado de Durango/Facultad de Agricultura y Zootecnia, Ejido Venecia, \\ Carretera Tlahualilo km 35, Gómez Palacio, Durango 35111, Mexico; garoma64@hotmail.com (M.Á.G.R.); \\ cirvaz60@hotmail.com (C.V.V.) \\ 4 Tecnologico Nacional de México/Instituto Tecnológico de Villahermosa. Ingeniería Química, \\ Bioquímica y Ambiental, Villahermosa, Tabasco 86010, Mexico; rantonio70@yahoo.com \\ * Correspondence: fortismanuel@hotmail.com
}

Received: 24 October 2018; Accepted: 12 November 2018; Published: 15 November 2018

\begin{abstract}
The objective of this research was to evaluate the production and phytochemical quality of cucumber (Cucumis sativus) fruits, in response to the foliar application of different seaweed extracts. This study was carried out under shadow mesh conditions in the autumn-winter agricultural cycle at the Instituto Tecnológico de Torreón, Torreón, Coahuila, Mexico. The experimental design was completely random, using six treatments with six repetitions each. The treatments evaluated were: Macrocystis pyrifera, Bryothamnion triquetrum, Ascophyllum nodosum, Grammatophora spp., Macrocystis integrifolia, and a control treatment with inorganic fertilization. The substrate used was a mixture of sand and vermicompost. The yield, commercial size, and phytochemical compounds of the fruit were evaluated. Results showed that the yield using Steiner solution $\left(6.75 \mathrm{~kg} \mathrm{~m}^{-2}\right)$ was higher than that obtained with Bryothamnion triquetrum algae $\left(6.07 \mathrm{~kg} \mathrm{~m}^{-2}\right)$. Regarding the phenolic content, the extracts surpassed the control treatment, with Macrocystis pyrifera and Macrocystis integrifolia being statistically equal, with values of 47.37 and $43.73 \mathrm{mg}$ equiv. of Ac. Gallic $100 \mathrm{~g}$ fresh weight, respectively. The antioxidant capacity by ABTS+ and DPPH+ methods was higher using the treatment with Macrocystis pyrifera algae with 149.4 and $454.1 \mu \mathrm{M}$ equiv Trolox/100 $\mathrm{g}$ fresh base, respectively. This treatment also presented the highest value of vitamin $C$ with $5.07 \mathrm{mg} / 100 \mathrm{~g}$ fresh base, being $27 \%$ greater than the control treatment. Algae extracts increased the quality of the fruits by obtaining the highest antioxidant capacity, making their use a viable option to minimize the application of conventional fertilizers, thereby attenuating the effects on the environment and improving the health of the population.
\end{abstract}

Keywords: cucumis sativus; nutraceutical; antioxidant; ABTS+, DPPH+

\section{Introduction}

The production of protected vegetables is one of the main export activities in Mexico because it occupies fourth place worldwide and first place in the North American continent [1]. The main 
crops produced are tomatoes $(70 \%)$, pepper $(16 \%)$, and cucumber $(10 \%)$, and the production of these vegetables is mainly located in the northwest (72\%) and center of the country (19\%) [2]. Cucumber is in great demand in the United States of America (USA) and has had an unprecedented growth in recent years. Its importation grew from 394,107 tons in 2002 to 459,242 in 2012 [3]. Of this import volume, 80\% comes from Mexico, which is the main exporting country to the USA [4]. Under protected agriculture conditions, the production of cucumber is two to nine times greater than in the open field, which depends on technological levels, nutrition management, and the control of climatological conditions which are key factors for achieving high yields in this type of system [5].

This crop's nutrition is an important factor in maximizing its production. There is an indiscriminate use of agrochemicals in several regions, and excessive cultural practices have created serious consequences for the environment. In addition, the high costs of fertilizers in Mexico have put them out of the reach of producers, resulting in low yields, low incomes, and low quality produce [6]. Furthermore, in the large market of imported vegetables, there is a growing tendency among consumers to accept "innovative, different", and suitable products that can contribute to an ever-healthier diet with less environmental impact on natural resources [7]. The implementation of biological control and organic nutrition with biofertilizers could reduce the dependence on agrochemicals and thus make the production less hazardous to the environment and the consumer. Additionally, the application of these products could reduce the use of chemical fertilizers, increase performance and stress resistance by water and temperature tensions, and positively influence their growth and physiology [8].

Seaweed extracts (SWE) provide an alternative, as they not only contain nitrogen, phosphorus, and potassium, but also present molecules with a very wide range of structures and can be composed of phytohormones or metabolically active plant extracts such as amino acids and organic acids [9]. Researchers $[10,11]$ point out that seaweed extracts contain a wide variety of plant growth-promoting substances such as auxins, cytokinins, betaines, gibberellins, and organic substances, including amino acids, macronutrients, and trace elements that improve crop yield and quality.

These extracts are natural bioactive materials soluble in water; they are also organic fertilizers that promote the germination of seeds and increase the development and yield of crops [12]. They have been used as nutritional supplements, bio-stimulants, or biofertilizers in agriculture and horticulture [13]. In recent years, the use of marine algae extracts as biofertilizers has allowed the partial substitution of conventional mineral fertilizers [14]. These can be used as liquid extracts for foliar and soil applications, or in granular form as soil improvers and fertilizer [15]. Seaweed extracts have also been used to increase germination, fruit weight, and yield in tomatoes [16]; to improve chlorophyll and carbohydrates contents, fruit diameter, yield, and vitamin C in cucumber plants, [9]; and to increase leaf area, number of leaves, fresh stems, and biomass in beans [17]. In Stevia plants (Stevia rebaudiana Bertoni), marine algae extracts have improved some morphological, anatomical, and chemical characteristics [18]. Research was carried out on the effects of three seaweed extracts, namely, Asparagopsis spp., Gelidium pectinutum, and the green algae Enteromorpha intestinalis, a commercial seaweed extract Algreen and compost on cucumber [9]. Results showed that the use of E. intestinelis, G. pectinutum, or commercial seaweed extracts with compost is considered a suitable application to improve vegetative growth and yield of cucumber plants. The effect of three commercial extracts of the brown seaweed, Ascophyllum nodosum, on phytochemical content and yield in cabbage plants under field conditions was evaluated [19]. They found that total phenolic content was higher in all seaweed-treated plants, with the highest increase recorded with AlgaeGreen $\left(3.51 \mathrm{ha}^{-1}\right)$. Similar increases were recorded in total flavonoid content. In another study investigating the effect of the seaweed liquid fertilizer (SLF) Rosenvigea intricata - with or without chemical fertilizer-on seed germination, growth, yield, and pigment content [20], it was found that $20 \%$ of SLF-with or without chemical fertilizer—shows a higher growth, yield, chlorophyll pigment, and soil profile compared to other concentrations. A significant improvement in the size of olives and the quality of olive oil was recorded in trees sprayed with an A. nodosum extract fortified with added nitrogen and boron [21]. 
El-Sharony et al. [22] reported that the use of algae extracts is very effective for improving fruit set, fruit retention, yield, and enhanced fruit quality of mango fruits.

Anbuchezhian et al. [23] also mention that the biofertilizers derived from marine algae form great biofertilizers and improve soil quality and yields considerably. Marine algal species Ascophyllum, Ecklonia, and Fucus are commonly utilized as fertilizers containing amounts of nitrogen and potassium comparable to animal manure and organic fertilizers, but with a low phosphorus content. Application rates, frequency, and timing of the treatments vary with species, season, geographical location, and local environmental variables. Important ancillary benefits of seaweed products for crop production include the improvement of damage caused by insects and bacterial or fungal diseases [24].

In view of the above and based on the importance being given to the growing protected horticulture in the Comarca Lagunera, the objective of this research was to improve the yield and phytochemical quality of cucumber via leaf application of different seaweed extracts.

\section{Materials and Methods}

This study was carried out in shade mesh at the Technological Institute of Torreon (ITT), located at km 7.5 of the old Torreon-San Pedro road, Municipality of Torreon, Coahuila, Mexico. The mesh was an Agro Shade model of $250 \mathrm{~m}^{2}$ with a maximum wind resistance of $120 \mathrm{~km} / \mathrm{h}$, and greater than $35 \mathrm{~m}^{2}$ load capacity. The mesh was $16 \times 10$ strands of stabilized monofilament of flat fabric at $50 \%$ shade. The structure was manufactured with materials in accordance with the Mexican standard for the design and construction of greenhouses NMX-E-255-CNCP-2008 [25].

The treatments evaluated were five biofertilizers formulated with seaweed extracts: $\mathrm{T} 1=$ Macrocystis pyrifera (Macro.), T2 = Bryothamnion triquetrum (Bryo), T3 = Ascophyllum nodosum (Asco.), T4 = Grammatophora spp. (Gramma), and T5 = Macrocystis integrifolia (Macro. integri). They were compared with a control treatment (T6) using Steiner solution (SS).

\subsection{Obtaining the Seaweed Extracts}

Algae Macrocystis pyrifera and Grammatophora spp. were collected in the Pacific Ocean off the coast of La Paz, Baja California Sur $\left(29^{\circ} 09^{\prime} \mathrm{N}, 110^{\circ} 19^{\prime} \mathrm{W}\right)$, Mexico. The algae were washed with distilled water and dried for 7-10 days at room temperature. For the preparation of the extracts, the dried algae were ground in mortar and sieved. Subsequently, the aqueous extract was obtained by performing an extraction with distilled water $1: 5(w / v)$ for $5 \mathrm{~h}$ with constant agitation at room temperature. It was then centrifuged at $800 \times g$ in a HealForce centrifuge (Beckman GS-GKR, Palo Alto, CA, USA) at $40{ }^{\circ} \mathrm{C}$ for $20 \mathrm{~min}$. Subsequently, each sample was crushed in a mill and used to determine the chemical composition by undergoing acid digestion.

Organic matter, N, F, K, Mg, Bo, $\mathrm{Zn}$, and $\mathrm{Si}$ were determined by atomic absorption spectrophotometry [26]. Then, $100 \mathrm{~g}$ of each sample was added to $1 \mathrm{~L}$ of distilled water with constant stirring for $15 \mathrm{~min}$ followed by autoclaving at $121^{\circ} \mathrm{C}$ for $1 \mathrm{~h}$ at $1.21 \mathrm{~kg} \mathrm{~cm}^{-2}$ [27]. The hot extracts were filtered through Whatman No. 40 filter paper and stored. In the case of the Bryothamnion triquetrum, Ascophyllum nodosum, and Macrocystis integrifolia algae, commercial algae existed on the market under the name of FulvimaxAT, SeaplantAT, and GaiaAT, respectively.

The aqueous solution was applied at 10\% concentration, via Foliar spray, at an average of $150 \mathrm{~mL}$ per plant according to the technical recommendation for horticultural crops. The applications were started eight days after the transplant and, subsequently, every two weeks up until 80 days after the transplant (dds).

The chemical characteristics of the algae are presented in Table 1. The experimental design was completely randomized with six treatments and six repetitions resulting in 36 experimental units. An analysis of variance (ANOVA) and the Tukey separation test $(p \leq 0.05)$ were performed using the statistical program SAS ver. 6.03 [28]. 
Table 1. Chemical composition of seaweed extracts evaluated in cucumber production.

\begin{tabular}{cccccc}
\hline Compound & $\begin{array}{c}\text { Macrocystis } \\
\text { pyrifera }\end{array}$ & $\begin{array}{c}\text { Bryothamnion } \\
\text { triquetrum }\end{array}$ & $\begin{array}{c}\text { Ascophyllum } \\
\text { nodosum }\end{array}$ & $\begin{array}{c}\text { Grammatophora } \\
\text { spp. }\end{array}$ & $\begin{array}{c}\text { Macrocystis } \\
\text { integrifolia }\end{array}$ \\
\hline Organic matter & 3.490 & 4.15 & $\% w / v$ \\
Nitrogen & 0.147 & 1.45 & n.a. & 3.500 & 2.944 \\
Phosphorus & 0.008 & 1.36 & 3.00 & 1.145 & 0.026 \\
Potassium & 0.077 & 1.48 & 5.30 & 0.020 & 0.005 \\
Magnesium & 0.0136 & n.a. & 0.1500 & 0.0200 & 1.310 \\
Boron & 0.0006 & n.a. & 0.0003 & n.a. & 0.0023 \\
Zinc & 0.00013 & 0.00075 & n.a. & 0.00025 & 0.00126 \\
Silicon & n.a. & 0.00027 & n.a. & n.a. & n.a. \\
\hline
\end{tabular}

Source: Technical specifications of the product. ${ }^{*}$ n.a. $=$ not available.

\subsection{Substrate Use}

The substrate was organic using the proportions $80 \%$ sand $+20 \%$ vermicompost. This substrate has been evaluated in several studies showing the best results for this vegetable [29]. The chemical and physical characteristics of the substrate are presented in Table 2.

Table 2. Chemical and physical composition of the organic substrate (sand:vermicompost) used in the evaluation of algae extracts in the shade-grown cucumber culture.

\begin{tabular}{cccc}
\hline Nutrient & \multicolumn{3}{c}{ Sand + Vermicompost (80:20 v/v) } \\
\hline Nitrate & $\mathrm{mg} \mathrm{kg}^{-1}$ & & \\
Phosphorus & 13.72 & Texture (sand-silt-clay) & $97-1-2$ \\
Carbonates & 15.33 & CEC (meq/100 g) & 9.00 \\
Potassium & 3.30 & $\mathrm{pH}$ & 7.91 \\
Iron & 198.5 & $\mathrm{OM}(\%)$ & 7.04 \\
Copper & 1.76 & EC $\left.(\mathrm{dS} \mathrm{m})^{-1}\right)$ & 3.21 \\
Zinc & 0.49 & $\mathrm{R}$ & 2.95 \\
Manganese & 0.53 & ESP & 2.99 \\
\hline
\end{tabular}

Source: Analyses carried out in the Laboratory of ITT and the Coop. Agrop. of Comarca Lagunera. $\mathrm{CEC}=$ Cation exchange capacity, $\mathrm{pH}=$ Hydrogen potential, $\mathrm{OM}=$ Organic matter, $\mathrm{EC}=$ Electric conductivity, $\mathrm{R}=$ Rate; $\mathrm{ESP}=$ Exchangeable sodium percentage.

A hydroponic substrate formulated with disinfected and sterilized river sand, along with pearlite in a ratio of 80:20 $(v / v)$, was used for the control treatment. The algae and the control treatments were established in polyethylene plastic pots, caliber 600 of $18 \mathrm{~kg}$ capacity.

\subsection{Agronomic Management of the Crop}

The experiment was carried out during the autumn-winter agricultural cycle. On 1 September, cucumber (Cucumis sativus L.) American type parthenocarpic, hybrid, Hisham-EZ 1110 was planted in 200-well polyethylene trays using the Premier Promix P6X peat moss substrate, using one seed per cavity. The handling of the trays consisted of maintaining the relative humidity $(80 \%)$ and adequate temperature $\left(25-27^{\circ} \mathrm{C}\right)$ for its development. The transplant to the pots took place 15 days after planting when the seedlings had a height between 5 and $7 \mathrm{~cm}$ and three to five true leaves. The pots were accommodated in such a way that the population density was four plants per square meter in double rows separated by $30 \mathrm{~cm}$, with a distance of $40 \mathrm{~cm}$ between pots and $1.5 \mathrm{~m}$ between rows.

The irrigation of the pots was on average $0.750-1.0 \mathrm{~L}$ of water per pot per day; this condition varied depending on the evaporation and environmental conditions within the shade mesh. The control treatment (SS) was irrigated with nutrient solution [30] every day applying an average of $0.750 \mathrm{~L}$ per pot. The solution (SS) was diluted at a rate of $30,50,75$, and $100 \%$ concentration according to the 
phenological stage of the culture. Organic products were used in the control of pests and diseases, which included organic repellents. A dose of $40 \mathrm{~mL}$ of neem extract and garlic extract in $20 \mathrm{~L}$ of water was applied once a day in the morning at eight-day intervals for the control of whitefly (Bemisia tabaci).

The agronomic management was in accordance with the usual practices of the producer of the region. The stems were trained vertically, sustained with polypropylene agricultural raffia yarn. All buds were eliminated below $40 \mathrm{~cm}$ of the main stem, and later on, all lateral buds were eliminated by weekly pruning, leaving one fruit per axilla, until the plant reached $2.0 \mathrm{~m}$ in height.

\subsection{Evaluated Variables}

For the analyses, nine mature cucumber samples were taken in each treatment. The length of the fruit was determined using a metal tape, with a precision of $1 \mathrm{~mm}$. A Mitutoyo digital caliper, model CD-6"CS (Mitutoyo corporation, Kanagawa, Japan), with a precision of $0.01 \mathrm{~mm}$ was used for the diameter of the fruit in $\mathrm{mm}$. The firmness of the fruits was measured using an Extech penetrometer (FHT200, Extech Instruments Corporation, Nashua, NH, USA) with a maximum capacity of $20 \mathrm{~kg} / 44.10 \mathrm{lb}$ or 196.10 Newton, and the average of two measurements per fruit was reported in Newton (N). The total soluble solids were measured with a $0 \%-32 \%$ manual refractometer (Sper scientific 300001, SPER SCIENTIFIC LTD, Scottsdale, AZ, USA) and the results were reported in ${ }^{\circ}$ Brix. A model AUY Shimadzu digital balance was used to weigh the fruit in grams, with a precision of $0.1 \mathrm{mg}$. The cucumber harvest was approximately 60 days after the transplant (daT); the fruits with commercial maturity were harvested, those with smooth and straight cylindrical surfaces, a dark, uniform green color (with no yellowing), considering the A category of 3.5-5.0 cm in diameter and $14.0-16.5 \mathrm{~cm}$ in length, according to the Mexico Supreme Quality mark, as the norm for commercial production [31]. The yield was obtained from all harvested fruits that fulfilled this consideration. The result was expressed in grams per plant $\left(g\right.$ plant $\left.{ }^{-1}\right)$ and kilograms per square meter $\left(\mathrm{km}^{-2}\right)$.

\subsection{Sample Preparation for Phytochemical Quality Analysis}

The harvested fruits were washed with drinking water for 2 min to remove residues and lyophilized for five days. Subsequently, the dry material was pulverized manually (using mortar and pestle) and stored in plastic tubes at $-18^{\circ} \mathrm{C}$ until extracts were obtained.

\subsubsection{Obtaining Extracts for Phytochemicals Analysis}

A portion of $250 \mathrm{mg}$ of dry sample was mixed in $5 \mathrm{~mL}$ of HPLC-grade methanol in plastic tubes with screw caps, which were placed on a rotary shaker (ATR Inc., EU, Thomas Scientific, Swedesboro, $\mathrm{NJ}$, USA.) for $24 \mathrm{~h}$ at $20 \mathrm{rpm}$ at room temperature $\left(25^{\circ} \mathrm{C}\right)$. Then, the tubes were centrifuged at $3000 \mathrm{rpm}$ for $5 \mathrm{~min}$ and the supernatant was removed for analysis.

\subsubsection{Total Phenolic Content}

The total phenolic content was measured using a modification of the Folin-Ciocalteau method [32]. The content was calculated by means of a standard curve using gallic acid (Sigma-Aldrich, St. Louis, $\mathrm{MO}, \mathrm{USA}$ ) as the standard, and the results were reported in $\mathrm{mg}$ of equivalent gallic acid per $\mathrm{g}$ of fresh base sample (mg equiv AG/g BF). The analyses were performed in triplicate.

\subsubsection{Equivalent Antioxidant Capacity in Trolox (ABTS+ Method)}

The equivalent antioxidant capacity in Trolox was evaluated using the in vitro ABTS+ (2,2'-azinobis (3-thylbenzthiozoline-6-sulphonic acid)) method published by Esparza-Rivera et al. [32]. The results were reported as equivalent antioxidant capacity in $\mathrm{mM}$ equivalent in Trolox per $\mathrm{g}$ fresh base $(\mathrm{mM}$ equiv Trolox g BF). 


\subsubsection{Equivalent Antioxidant Capacity in Trolox (DPPH+ Method)}

In addition, the antioxidant capacity was evaluated using the DPPH+ (1,1-diphenyl-2picrylhydrazil) in vitro method [33]. The results were reported as equivalent antioxidant capacity in $\mu \mathrm{M}$ equivalent in Trolox per $\mathrm{g}$ fresh base ( $\mu \mathrm{M}$ equiv Trolox $/ 100 \mathrm{~g}$ BF).

\subsection{Vitamin C Content}

The vitamin $C$ content was determined using a modification of the chromatograph method cited by Esparza-Rivera et al. [32]. The extract obtained was filtered through a membrane filter of $0.45 \mu \mathrm{m}$ before being injected into high-resolution chromatography equipment (Hewlett-Packard, 1200 Series, Palo Alto, CA, USA) using the Chem Station software for CL (Agilent Technologies, Palo Alto, CA, USA). The ascorbic acid (vitamin C) was eluted on a C18 Supelco column $(150 \mathrm{~mm} \times 5.0 \times 0.5 \mathrm{~cm})$ at a flow rate of $0.5 \mathrm{~mL} / \mathrm{min}$, using a 50:50 mixture of phosphoric acid $0.5 \%$ and methanol (chromatograph grade) as the mobile phase. The effluent was monitored at $254 \mathrm{~nm}$ in a diode array detector. The results were obtained using a standard curve for ascorbic acid (Sigma-Aldrich) and reported as $\mathrm{mg}$ of ascorbic acid per $\mathrm{g}$ fresh sample. The analyses were performed in duplicate.

\section{Results and Discussion}

\subsection{Fruit Size}

The length and diameter of the fruit, as well as the weight and concentration of soluble solids, were better in the chemical treatment (SS), as seen in Table 3. The best treatment of algae extracts for affecting the size of the fruit was the Bryothamnion triquetrum algae, being statistically equal to the control treatment. Regarding diameter, the Macrocystis integrifolia algae was statistically equal to the control and, with respect to SST, the Macrocystis pyrifera algae showed the lowest value (see Table 3). Abdel-Mawgoud et al. [34] reported that the enhanced vegetative growth by seaweed extract was reflected on fruit growth where fruit weight and diameter were enhanced as well. These may be brought about by more assimilates going to the fruits and/or more enhancement in sink strength of the fruits to attract more water and assimilates.

Table 3. Diameter, length, weight, and total soluble solids of cucumber fruits in shaded house conditions, with foliar applications of algae extracts.

\begin{tabular}{|c|c|c|c|c|}
\hline \multirow{2}{*}{ Treatment } & \multicolumn{2}{|c|}{ Fruit Size } & \multirow{2}{*}{ Weight } & \multirow{2}{*}{ Total Soluble Solids } \\
\hline & Length & Diameter & & \\
\hline & \multicolumn{2}{|c|}{$\mathrm{cm}$} & $\mathrm{g}$ fruit $^{-1}$ & ${ }^{\circ}$ Brix \\
\hline $\mathrm{T} 1$ & $13.36 \pm 0.757 \mathrm{~d}$ & $3.38 \pm 0.026 \mathrm{~d}$ & $154.3 \pm 4.041 \mathrm{e}$ & $3.44 \pm 0.569 \mathrm{~b}$ \\
\hline $\mathrm{T} 2$ & $16.23 \pm 0.351 \mathrm{a}$ & $4.54 \pm 0.073 c$ & $263.0 \pm 3.000 \mathrm{~b}$ & $4.76 \pm 0.098 \mathrm{a}$ \\
\hline $\mathrm{T} 3$ & $15.30 \pm 0.200 \mathrm{c}$ & $4.64 \pm 0.015 \mathrm{~b}$ & $219.0 \pm 6.244 c$ & $4.59 \pm 0.036 \mathrm{a}$ \\
\hline $\mathrm{T} 4$ & $15.46 \pm 0.251 \mathrm{ab}$ & $4.61 \pm 0.017 \mathrm{bc}$ & $207.6 \pm 5.131 \mathrm{~d}$ & $4.91 \pm 0.062 \mathrm{a}$ \\
\hline $\mathrm{T} 5$ & $15.56 \pm 0.305 b c$ & $4.77 \pm 0.028 \mathrm{a}$ & $207.3 \pm 4.509 \mathrm{~d}$ & $4.70 \pm 0.020 \mathrm{a}$ \\
\hline T6 & $16.76 \pm 0.152 \mathrm{a}$ & $4.85 \pm 0.015 \mathrm{a}$ & $282.6 \pm 9.291 \mathrm{a}$ & $4.74 \pm 0.055 \mathrm{a}$ \\
\hline MSD & 1.183 & 0.104 & 17.258 & 0.720 \\
\hline $\mathrm{SE}$ & 0.174 & 0.001 & 37.033 & 0.064 \\
\hline $\mathrm{CV}$ & 2.699 & 0.824 & 2.737 & 5.617 \\
\hline
\end{tabular}

Values with equal letters within each column are statistically similar (Tukey, $p \leq 0.05$ ). MSD = Minimum Significant Difference; $\mathrm{SE}=$ Standard Error; CV = Coef. Var. T1 (Macrocystis pyrifera), T2 (Bryothamnion triquetrum), T3 (Ascophyllum nodosum), T4 (Grammatophora spp.), T5 (Macrocystis integrifolia), T6 (Steiner solution).

DeGannes et al. [35] have indicated that the length of the American cucumber fluctuates between 20 and $25 \mathrm{~cm}$, and not under $15 \mathrm{~cm}$ [31]. For the diameter of the fruit, Farrag et al. [36] found an average diameter of $3.17 \mathrm{~cm}$ with seaweed extract; likewise, Wittwer and Honma [37] found that the diameter of cucumber fluctuates from 5.0 to $5.7 \mathrm{~cm}$, and should not exceed $6.0 \mathrm{~cm}$. From the results, 
it can be observed that the foliar applications of the algae extracts showed similar values to those obtained in the control treatment. This result can be attributed to the benefits of algae when used in horticultural crops. In this regard, Bajpai [38] indicated that algae present active organic compounds as growth regulators. Metting et al. [39] have indicated that the physiological responses derived from the application of marine algae include greater nutrient mobilization, the development of a vigorous root system, an increase in chlorophyll content and leaf area, and a delay in fruit senescence.

\subsection{Total Soluble Solids}

Regarding the content of total soluble solids (SST), the treatments Bryothamnion triquetrum (T2), Ascophyllum nodosum (T3), Grammatophora spp. (T4), and Macrocystis integrifolia (T1) were statistically equal to the treatment with Steiner solution (SS), with an average value of $4.76^{\circ}$ Brix, and different from the treatment with Macrocystis pyrifera algae which decreased the SST by $29 \%$ (Table 3). Colapietra and Alexander [40] observed an increment of up to $17^{\circ}$ Brix in a table grape crop (cv Italia) with foliar application of seaweed extracts Ascophyllum nodosum.

Similarly, Khan et al. [41] reported increments of $28 \%$ of total sugars in Perville cv Vine by applying Ascophyllum nodosum. On the other hand, Kumari et al. [42] mentioned a higher concentration of total soluble sugars in the tomato crop with soil and foliar applications of seaweed extract Sagarssum johntonii.

\subsection{Fruit Weight ( $g$ fruit $\left.^{-1}\right)$}

The weight of the American cucumber fruit should fluctuate between 300 and $400 \mathrm{~g}$. In this study, the different algae extracts caused significant differences in weight $(p \leq 0.05)$, with the control treatment (SS) having the greatest weight (Table 3). Regarding treatments with algae extracts, the Bryothamnion triquetrum treatment was the best, with a $7 \%$ lower weight than that of the control, but $41 \%$ higher than that of the treatment with Macrocystis pyrifera, which obtained the lowest weight. The differences in the weight of the American cucumber found in this study may be due to different hybrids, different climate conditions, and crop management. The specifications PC-021-2005 for the use of the official Mexico mark [31] establishes two types of cucumber in relation to its attributes. The fruits obtained in this study fall into the classification B (diameter $5.1-6.5 \mathrm{~cm}$ and length 14-16.5 cm) and, therefore, could compete in the national and international markets.

\subsection{Cucumber Yield}

The statistical analysis for this variable shows significant differences $(p \leq 0.05)$ in the yield $\left(\right.$ g plant $^{-1}$ ) (Figure 1). The control treatment with Steiner solution reported the highest yield, being $9 \%$ higher than the best yield obtained with the algae extracts. The treatment with the Bryothamnion triquetrum algae showed a $42 \%$ higher yield compared to the lower yield obtained with the Macrocystis pyrifera algae. The higher yield obtained with Bryothamnion triquetrum may be due to its greater effect on nutrient absorption. In this regard, Youssef et al. [43] have indicated that the higher production of biomass and yield in cucumber plants could be attributed to the fact that the plants inoculated with biofertilizers have a greater capacity to maintain a high rate of net photosynthesis and a better nutritional status (high concentration of $\mathrm{P}, \mathrm{K}, \mathrm{Mg}, \mathrm{Fe}, \mathrm{Zn}$, and $\mathrm{Mn}$ ) compared to non-inoculated plants. Likewise, Metting et al. [39] have mentioned that the physiological responses derived from the application of seaweed include the greater mobilization of nutrients, the development of a vigorous root system, an increase in the chlorophyll content and leaf area, and a delay in fruit senescence.

It was observed that the control treatment (SS) presented the highest yield per square meter $\left(\mathrm{kg} \mathrm{m}^{-2}\right.$ ). The treatments with algae extracts showed values between 2.54 and $6.08 \mathrm{~kg} \mathrm{~m}^{-2}$ (see Figure 1). Regarding the performance in protected systems in Mexico, according to Servicio de Información Agroalimentaria y Pesquera (SIAP) [44] reports, the average yield of cucumber is $98 \mathrm{t} \cdot \mathrm{ha}^{-1}$ $\left(9.8 \mathrm{~kg} \mathrm{~m}^{-2}\right)$. For example, the average yield for this shade mesh culture is $17.6 \mathrm{~kg} \mathrm{~m}^{-2}$ in the state of Baja California (Mexico) [45]. In the case of the Comarca Lagunera (Mexico), with medium-tech 
production technology in shade mesh and fertigation, for six plants, the yield fluctuates between 14 and $17 \mathrm{~kg} \mathrm{~m}^{-2}$ [46].

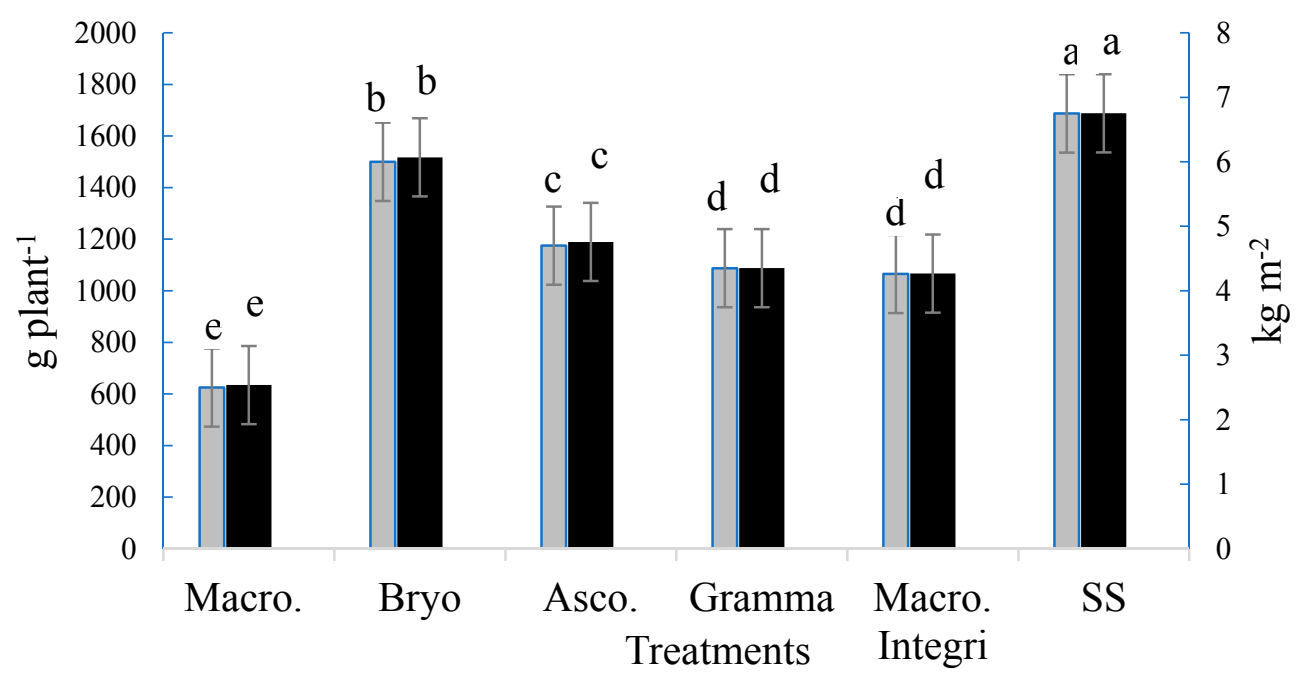

Figure 1. Effect of foliar application of seaweed extracts on the cucumber yield based on $\mathrm{g}_{\text {plant }}{ }^{-1}$ (black bars) and $\mathrm{kg} \mathrm{m}^{-2}$ (grey bars) established in shade mesh. Means followed by the same letter are not significantly different between treatments (Tukey; $p \leq 0.05$ ). Macro. $=$ Macrocystis pyrifera, Bryo = Bryothamnion triquetrum, Asco. = Ascophyllum nodosum, Gramma = Grammatophora spp., Macro. integri = Macrocystis integrifolia, $\mathrm{SS}=$ Steiner solution.

Comparing the benefits of the yields obtained in this experiment to those using chemical fertilization and algae, it can be mentioned that the latter are greater because they are friendly to the environment. The trend in the future is to produce organic cucumbers since they have a high consumer demand. The pricing of these products in the foreign market could be higher in relation to the pricing given to conventional products and, consequently, it would improve the cost-benefit ratio of their production.

\subsection{Phytochemical Quality}

\subsubsection{Antioxidants}

The phytochemical quality of the fruits (antioxidants) was influenced by the algae extracts $(p \leq 0.05)$. Higher values of antioxidants were obtained with the Macrocystis pyrifera algae (Table 4). Regarding the antioxidant capacity, under both determination methods (ABTS+ and DPPH+), Macrocystis pyrifera showed the highest value, followed by Bryothamnion triquetrum. Both values were statistically different from each other and different from the control treatment, exceeding it by $30 \%$ and $4 \%$, respectively. With the DPPH+ method, the treatment with chemical fertilization presented the lowest value. These results can be explained considering the nutrient deficiency that the substrate presents, particularly that of nitrogen for the plant. In this regard, Lorio [47] and Herms and Mattson [48] mentioned that plants produce higher amounts of sugars and secondary metabolites when they are subjected to a deficit of readily available nitrogen.

However, the results obtained contrast with those found by Santiago-López et al. [49] in which organic sources of fertilization were used for cucumber, obtaining antioxidant capacity values of 779.9 to $1391.1 \mu \mathrm{M}$ equiv Trolox/100 g BF. On the other hand, Díaz-Méndez et al. [29] used different proportions of vermicompost and obtained antioxidant capacity values between 749.9 and 1015.2. Some studies have shown that high concentrations of $\mathrm{NaCl}$ in substrates increase the activity of antioxidant enzymes $[50,51]$. This result has been attributed to the synthesis of phenols by plants as 
a defense mechanism to counteract the negative effects of oxidative stress [52]. Therefore, phenolic compounds are the main drivers of antioxidant activity [53].

Table 4. Antioxidant capacity of cucumber produced in shade mesh with the application of different nutrient solutions derived from algae, using two methods (ABTS+ and DPPH+).

\begin{tabular}{ccc}
\hline Treatments & CAOX * (ABTS+ Method) & CAOX ** $^{*}$ (DPPH+ Method) \\
\hline Macrocystis pyrifera & $149.4 \pm 13.7 \mathrm{a}$ & $454.1 \pm 45.0 \mathrm{a}$ \\
Bryothamnion triquetrum & $110.4 \pm 7.6 \mathrm{~b}$ & $373.9 \pm 29.0 \mathrm{bc}$ \\
Ascophyllum nodosum & $90.6 \pm 3.4 \mathrm{c}$ & $295.9 \pm 19.0 \mathrm{~d}$ \\
Grammatophora spp. & $77.0 \pm 7.5 \mathrm{~d}$ & $278.4 \pm 20.1 \mathrm{~d}$ \\
Macrocystis integrifolia & $120.4 \pm 12.7 \mathrm{~b}$ & $403.5 \pm 25.4 \mathrm{~b}$ \\
Steiner Solution (SS) & $105.9 \pm 8.0 \mathrm{~b}$ & $349.7 \pm 24.3 \mathrm{c}$ \\
MSD & 21.9 & 70.4 \\
SE & 81.6 & 836.3 \\
CV & 8.5 & 8.2
\end{tabular}

* CAOX: Antioxidant capacity (ABTS+ method), results in $\mu \mathrm{M}$ equiv Trolox $/ 100 \mathrm{~g}$ fresh base. ${ }^{* *}$ CAOX: Antioxidant capacity (DPPH+ method), results in $\mu \mathrm{M}$ equiv Trolox $/ 100 \mathrm{~g}$ fresh base. MSD = Minimum Significant Difference; $\mathrm{SE}=$ Standard Error; $\mathrm{CV}=$ Coef. Var. Differences between means obtained by Tukey test $(p \leq 0.05)$. Values in columns with different lowercase letters are statistically different $(p \leq 0.05)$.

\subsubsection{Phenolic Content}

With respect to the phenolic content (Figure 2), the Macrocystis pyrifera algae had the highest value (47.37). The lowest value was in Grammatophora spp., which was expected since it generated respectively the highest and the lowest antioxidant capacity. The treatment with Steiner solution presented 36.03 for phenolic content and 3.7 for vitamin C, similar to Bryothamnion triquetrum. These results show a significant increase in the total phenolic content relative to the control; this can be due to osmotic stress or an increase in plant hormone activities caused by the seaweed application [54].

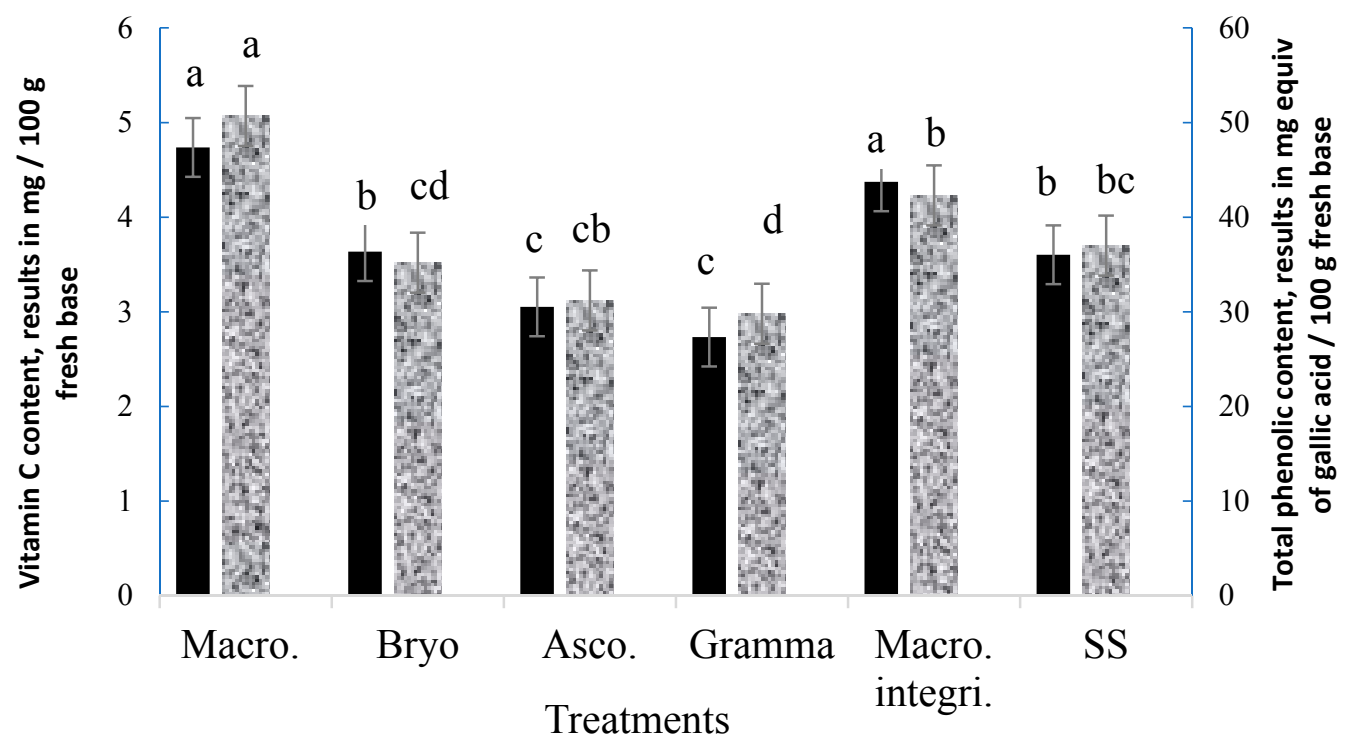

Figure 2. Total phenolic (black bars) and vitamin C content (grey bars) of cucumber produced in shade mesh with the application of different nutrient solutions derived from algae. Means followed by the same letter are not significantly different between treatments (Tukey; $p \leq 0.05$ ). Macro. = Macrocystis pyrifera, Bryo = Bryothamnion triquetrum, Asco. = Ascophyllum nodosum, Gramma = Grammatophora spp., Macro. integri = Macrocystis integrifolia, $\mathrm{SS}=$ Steiner solution. 


\subsubsection{Vitamin C}

Cucumber provides a large amount of vitamin C (mg/100 $\mathrm{g}$ fresh base) and, in this experiment, the treatments with the highest content were the algae Macrocystis pyrifera (5.07) and Macrocystis integrifolia (4.23) and the control treatment (3.70) (Figure 2). The algae Grammatophora spp. presented the lowest value-41\% lower compared to Macrocystis pyrifera. Nagy and Pintér [55] have pointed out that the positive effect of seaweed extract can be explained by the high content of high-quality proteins, amino acids such as lysine and tryptophan, essential minerals, trace elements, B-complex vitamins, and bio-constituents, especially cytokinins.

\section{Conclusions}

Higher yields and commercial quality were obtained in cucumber fruits using chemical fertilization, mainly due to the higher concentration of $\mathrm{N}$ and the ionic balance of the nutritive solution. Of the treatments with algae extracts, Bryothamnion triquetrum was superior in total soluble solids, fruit firmness, fruit size, and yield. However, the highest antioxidant capacity, phenols, and vitamin $C$ were obtained with the Macrocystis pyrifera extract. The algae extracts provided some phyto-nutrients for the nutrition of the cucumber plants and increased the quality of the fruits by obtaining greater antioxidant capacity. In conclusion, this study demonstrated that foliar spraying of seaweed extract induced positive effects on the plant growth, fruit yield, and quality of cucumber fruits. Therefore, the use of biofertilizers could reduce the dependence on agrochemicals and thus make the production more sustainable for the environment and for the consumer.

Author Contributions: Data curation, P.P.R. and M.A.G.R.; Formal analysis, P.P.R.; Investigation, L.S.A. and M.F.H.; Visualization, R.d.C.A.C. and C.V.V.; Writing—original draft, R.T.V. and M.A.G.R.; Writing-review and editing, M.F.H.

Funding: Please add: “This research was funded by Tecnologico Regional de Mexico grant number 5897.16-P.

Acknowledgments: This study was supported by Tecnológico Nacional de México (TecNM), 2018.

Conflicts of Interest: The authors declare no conflict of interest.

\section{References}

1. United States Department of Agriculture (USDA). National Agricultural Statistics Service. Available online: https:/ / www.nass.usda.gov/Publications/Ag_Statistics/2014/ (accessed on 17 August 2017).

2. Secretaría de Ganadería Agricultura Pesca y Alimentación (SAGARPA). Programa de Ejecución Directa de Agricultura Protegida. Secretaría de Agricultura Ganadería, Pesca y Alimentación. Available online: http:/ /2006-2012.sagarpa.gob.mx/agricultura/Paginas/Agricultura-Protegida2012.aspx (accessed on 18 December 2016).

3. Food and Agriculture Organization of the United Nations Statistical (FAOSTAT). FAO Statistical Pocketbook Word Food and Agriculture. Available online: http://www.fao.org/faostat/es/\#data (accessed on 17 February 2016).

4. Fideicomisos Instituidos en Relación con la Agricultura (FIRA). TLCAN Agropecuario: Expectativas y tendencias recientes. Available online: https://www.fira.gob.mx/InfEspDtoXML/abrirArchivo.jsp? abreArc=19440 (accessed on 15 March 2017).

5. Fundación Mexicana para la Investigación Agropecuaria y Forestal (FUMIAF). Cultivo de Pepino Europeo en Invernaderos de Alta Tecnología en México; ONGs y Asociaciones Civiles: Mexico City, Mexico, 2005; p. 37.

6. Basak, R. Benefits and Costs of Nitrogen Fertilizer Management for Climate Change Mitigation: Focus on India and Mexico. CCAFS Working Paper No. 161. CGIAR Research Program on Climate Change, Agriculture and Food Security (CCAFS): Copenhagen, Denmark. Available online: www.ccafs.cgiar.org (accessed on 20 May 2017).

7. United Nations Enviroment Programme-International Resource Panel (UNEP-IRP). Food Systems and Natural Resources. Printed: UNESCO. Available online: http:/ / www.unep.org/resourcepanel (accessed on 15 August 2017). 
8. Shaheen, M.A.; Abd ElWahab, S.M.; El-Morsy, F.M.; Ahmed, A.S.S. Effect of organic and bio-fertilizers as a partial substitute for NPK mineral fertilizer on vegetative growth, leaf mineral content, yield and fruit quality of superior grapevine. J. Hortic. Sci. Ornam. Plants 2013, 5, 151-159.

9. Ahmed, Y.M.; Shalaby, E.A. Effect of different seaweed extracts and compost on vegetative growth, yield and fruit quality of cucumber. J. Hortic. Sci. Orna. Plants 2012, 4, 235-240.

10. Abd El Moniem, E.A.; Abd-Allah, A.S.E. Effect of Green Alga Cells Extract as Foliar Spray on Vegetative Growth, Yield and Berries Quality of Superior Grapevines. Am.-Eur. J. Agric. Environ. Sci. 2008, 4, 427-433.

11. Sathya, R.; Kanaga, N.; Sankar, P.; Jeeva, C. Antioxidant properties of phlorotannins from brown seaweed Cystoseira trinodis (Forsskål) C. Agardh. Arab. J. Chem. 2013, 10, S2608-S2614. [CrossRef]

12. Norrie, J.; Keathley, J.P. Benefits of Ascophyllum nodosum marine-plant extract applications to 'Thompson seedless' grape production. Acta Hortic. 2006, 727, 243-247. [CrossRef]

13. Van Oosten, M.J.; Pepe, O.; de Pascale, S.; Silletti, S.; Maggio, A. The role of biostimulants and bioeffectors as alleviators of abiotic stress in crop plants. Chem. Biol. Technol. Agric. 2017, 5, 1-12. [CrossRef]

14. Zodape, S.T.; Gupta, A.; Bhandari, S.C.; Rawat, U.S.; Chaudhary, D.R.; Eswaranand, K.; Chikara, J. Foliar application of seaweed sap as biostimulant for enhancement of yielf and quality of tomato (Lycopersicon esculentum Mill.). J. Sci. Ind. Res. 2011, 70, 215-219.

15. Thirumaran, G.; Arumugam, M.; Arumugam, R.; Anantharaman, P. Effect of seaweed liquid fertilizer on growth and pigment concentration of Cyamopsis tetragonoloba (L.) Taub. Am. Eur. J. Agron. 2009, 2, 50-56.

16. Sutharsan, S.; Nishanthi, S.; Srikrishna, S. Effects of Foliar Application of Seaweed (Sargassum crassifolium) Liquid Extract on the Performance of Lycopersicon esculentum Mill. In sandy Regosol of Batticaloa District Sri Lanka. Am.-Eur. J. Agric. Environ. Sci. 2014, 14, 1386-1396.

17. Yehia, Y.I.A.; El-Miniawy, S.E.D.M.; El-Azm, N.A.A.; Hegazi, A.Z. Response of snap bean growth and seed yield to seed size, plant density and foliar application with algae extract. Ann. Agric. Sci. 2016, 61, 187-199.

18. Salama, E.S.; Kabra, A.N.; Ji, M.K.; Kim, J.R.; Min, B.; Jeon, B.H. Enhancement of microalgae growth and fatty acid content under the influence of phytohormones. Bioresour. Technol. 2014, 172, 97-103. [CrossRef] [PubMed]

19. Lola-Luz, T.; Hennequart, F.; Gaffney, M. Enhancement of phenolic and flavonoid compounds in cabbage (Brassica oleraceae) following application of commercial seaweed extracts of the brown seaweed (Ascophyllum nodosum). Agric. Food Sci. 2013, 22, 288-295. [CrossRef]

20. Thirumaran, G.; Arumugam, M.; Arumugam, R.; Anantharaman, P. Effect of Seaweed Liquid Fertilizer on Growth and Pigment Concentration of Abelmoschus esculentus (L) medikus. Am.-Eurasian J. Agron. 2009, 2, $57-66$.

21. Chouliaras, V.; Tasioula, M.; Chatzissavvidis, C.; Therios, I.; Tsabolatidou, E. The effects of a seaweed extract in addition to nitrogen and boron fertilization on productivity, fruit maturation, leaf nutritional status and oil quality of the olive (Olea europea) cultivar Koroneiki. J. Sci Food Agric. 2009, 89, 984-988. [CrossRef]

22. El-Sharony, T.F.; El-Gioushy, S.F.; Amin, O.A. Effect of Foliar Application with Algae and Plant Extracts on Growth, Yield and Fruit Quality of Fruitful Mango Trees Cv. Fagri Kalan. J. Hortic. 2015, 2, 1-6.

23. Anbuchezhian, R.; Karuppiah, V.; Li, Z. Prospect of Marine Algae for Production of Industrially Important Chemicals; Department of Biotecnology, Indian Institute of Technology: Kharagpur, India, 2015.

24. Craigie, J.S. Seaweed extract stimuli in plant science and agriculture. J. Appl. Phycol. 2011, 23, 371-393. [CrossRef]

25. Diario Oficial de la Federación (DOF). Norma Mexicana para el diseño y construcción de invernaderos NMX-E.-255-CNCP-2008. Available online: http://www.dof.gob.mx/normasOficiales/3434/seeco1/seeco1. $\mathrm{htm}$ (accessed on 9 December 2017).

26. AOAC Official Methods of Analysis of the Association of Analytical Chemists, 15th ed.; Association of Official Analytical Chemists: Gaithersburg, MD, USA, 1990.

27. Hernández-Herrera, R.M.; Santacruz-Ruvalcaba, F.; Ruiz-López, M.A.; Norrie, J.; Hernández-Carmona, G. Effect of liquid seaweed extracts on growth of tomato seedlings (Solanum lycopersicum L.). J. Appl; Phycol. 2014, 26, 219-268. [CrossRef]

28. Institute Inc. SAS User's Guide, Statistical Analysis System (SAS), Statistics, version 6.03; SAS Institute Inc.: Cary, NC, USA, 1999.

29. Méndez, H.D.; Rangel, P.P.; Reyna, V.Á.; Hernández, M.F.; Hernández, J.L.G. Producción orgánica y capacidad antioxidante de frutos de pepino. ITEA-Inf. Técnic. Econ. Agraria 2014, 110, 335-342. 
30. Steiner, A.A. The universal nutrient solution. In Proceedings of the 6 th International Congress on Soilless Culture, Lunteren, Netherlands, 2 May 1984; pp. 633-649.

31. Marca Oficial México Calidad Suprema en pepino (MCS). Especificaciones PC-021-2005. Pliego de condiciones para el uso de la Marca Oficial México Calidad Suprema en pepino. Bancomex. Available online: http: / / www.mexicocalidadsuprema.org/assets/galeria/PC_021_2005_Pepino.pdf (accessed on 21 June 2017).

32. Esparza-Rivera, J.R.; Stone, M.B.; Stushnoff, C.; Pilon-Smits, E.; Kendall, P.A. Effects of ascorbic acid applied by two hydrocooling methods on physical and chemical properties of green leaf lettuce stored at $5{ }^{\circ} \mathrm{C}$. J. Food Sci. 2006, 71, 270-276. [CrossRef]

33. Brand-Williams, W.; Cuvelier, M.E.; Berset, C. Used of a free method to evaluate antioxidant activity. LWT-Food Sci. Technol. 1995, 28, 25-30. [CrossRef]

34. Abdel-Mawgoud, A.M.R.; Tantaway, A.S.; Hafez, M.M.; Habib, H.A. Seaweed Extract Improves Growth, Yield and Quality of Different Watermelon Hybrids. Res. J. Agric. Biol. Sci. 2010, 6, 161-168.

35. DeGannes, A.; Heru, K.R.; Mohammed, A.; Paul, C.; Rowe, J.; Sealy, L.; Seepersad, G. Tropical Greenhouse Manual for the Caribbean; CARDI: St. Augustine, Trinidad and Tobago, 2014; p. 157.

36. Farrag, D.K.H.; Omara, A.A.; El-Said, M.N. Significance of Foliar Spray with Some Growth Promoting Rhizobacteria and Some Natural Biostimulants on Yield and Quality of Cucumber Plant. Egypt. J. Hort. 2015, 42, 321-332.

37. Wittwer, S.H.; Honma, S. Greenhouse tomatoes, lettuce, and cucumbers. Section 3, Greenhouse cucumbers. Michigan State University, USA. Available online: http://www.lpl.arizona.edu/ bcohen/cucumbers (accessed on 20 March 2017).

38. Bajpai, V.K. Antimicrobial bioactive compounds from marine algae: A. mini review. Indian J. Geo-Marine Sci. 2016, 45, 1076-1085.

39. Metting, B.; Zimmerman, W.J.; Crouch, I.; van Staden, J. Agronomic uses of seaweed and microalgae. In Introduction to Applied Phycology; Akatsuka, I., Ed.; SPB: The Hague, The Netherland, 1990; pp. 589-627.

40. Colapietra, M.; Alexander, A. Effect of foliar fertilization on yield and quality of table grapes. In $V$ International Symposium on Mineral Nutrition of Fruit Plants; International Society for Horticultural Science: Talca, Chile, 2005; Volume 721, pp. 213-218.

41. Khan, S.; Ahmad, B.; Jaskani, M.J.; Ahmad, R.; Malik, A.U. Foliar application of mixture of amino acids and seaweed (Ascophylum nodosum) extract improve growth and physicochemical properties of grapes. Int. J. Agric. Biol. 2012, 14, 383-388.

42. Kumari, R.; Kaur, I.; Bhatnagar, A.K. Effect of aqueous extract of Sargassum johnstonii Setchell and Gardner on growth, yield and quality of Lycopersicum esculentum Mill. J. Appl. Phycol. 2011, 23, 623-63. [CrossRef]

43. Youssef, R.; Cardarelli, M.; Mattia, E.; Tullio, M.; Rea, E.; Colla, G. Enhancement of alkalinity tolerance in two cucumber genotypes inoculated with an arbuscular mycorrhizal biofertilizer containing Glomus intraradices. Biol. Fert. Soils. 2010, 46, 499-509.

44. Servicio de Información Agroalimentaria y Pesquera (SIAP). Producción Agropecuaria y Pesquera, Sistema de Información Agroalimentaria de Consulta (SIACON). Available online: http://www.siap.gob.mx/ produccion-agropecuaria/ (accessed on 7 August 2016).

45. Vázquez-Angulo, J.C.; Grimaldo-Juárez, O.; González-Mendoza, D. Producción de Cucumis sativus en el valle de Mexicali, Baja California, México. IDESIA 2013, 31, 17-20. [CrossRef]

46. Secretaría de Agricultura, Ganadería, Desarrollo Rural, Pesca y Alimentación (SAGARPA). Estadísticas Agropecuarias de la Región Lagunera. Available online: http://www.sagarpa.gob.mx/Delegaciones/ regionlagunera/Paginas/default.aspx (accessed on 21 March 2017).

47. Lorio, P.L., Jr. Growth-differentiation balance a basis for understanding southern pine beetletree interations. For. Ecol. Manag. 1986, 14, 259-273. [CrossRef]

48. Herms, D.A.; Mattson, W.J. The dilemma of plants: To grow or to defend. Q. Rev. Biol. 1992, 67, $283-335$. [CrossRef]

49. Santiago-López, G.; Preciado-Rangel, P.; Sánchez-Chávez, E.; Esparza-Rivera, J.R.; Fortis-Hernández, M.; Alejandro Moreno-Reséndez, A. Organic nutrient solutions in production and antioxidant capacity of cucumber fruits. Emir. J. Food Agric. 2016, 28, 518-521. [CrossRef]

50. D'Amico, M.; Pardossi, A. Application of diluted sea water to soilless culture of tomato (Lycopersicon esculentum Mill.): Effects on plant growth, yield, fruit quality and antioxidant capacity. JFAE 2003, 1, 112-116. 
51. Sgherri, T.; Navari-Izzo, F.; Pardossi, A.; Soressi, G.P.; Izzo, R. The Influence of Diluted Seawater and Ripening Stage on the Content of Antioxidants in Fruits of Different Tomato Genotypes. J. Agric. Food Chem. 2007, 55, 2452-2458. [CrossRef] [PubMed]

52. Meloni, D.A.; Gulotta, M.R.; Oliva Cano, M.A. El estrés salino incrementa la actividad de enzimas antioxidantes y la concentración de polifenoles en Vinal (Prosopis ruscifolia G.). Quebracho-Rev. Cienc. For. 2008, 15, 27-31.

53. Faezah, O.N.; Aishah, H.S.; Kalsom, U. Comparative evaluation of organic and inorganic fertilizers on total phenolic, total flavonoid, antioxidant activity and cyanogenic glycosides in cassava (Manihot esculenta). Afric. J. Biotechnol. 2013, 18, 2414-2421.

54. Lola-Luz, T.; Hennequart, F.; Gaffney, M. Effect on yield, total phenolic, total flavonoid and total isothiocyanate content of two broccoli cultivars (Bassica oleraceae var italica) following the application of a comemmercial brown seaweed extract (Ascophyllum nodosum). Agric. Food Sci. 2014, 23, 28-37. [CrossRef]

55. Nagy, P.T.; Pintér, T. Effects of Foliar Biofertilizar Spray on Nutrient Uptake, Yield, and Quality Parameters of Blaufrankish (Vitis vinifera L.) Grapes. Commun. Soil Sci. Plant Anal. 2015, 46, 219-227. [CrossRef]

(C) 2018 by the authors. Licensee MDPI, Basel, Switzerland. This article is an open access article distributed under the terms and conditions of the Creative Commons Attribution (CC BY) license (http:/ / creativecommons.org/licenses/by/4.0/). 